\title{
Pengujian hasil dan mutu benih beberapa varietas kedelai dengan variasi jumlah satuan panas panen
}

\author{
Examination of yield and seed quality of several soybean varieties by variation of harvest \\ thermal total unit
}

\author{
INDRA DWIPA", WIDYA SASWITA \\ Jurusan Budidaya Pertanian, Fakultas Pertanian, Universitas Andalas. Kampus Universitas Andalas Limau Manis, Pauh, Padang 25163, Sumatera Barat. \\ Tel.: +62-751-72701, `email: 1965indradwipa@gmail.com
}

Manuskrip diterima: 7 September 2016. Revisi disetujui: 19 Januari 2017.

\begin{abstract}
Abstrak. Dwipa I, Saswita W. 2016. Pengujian hasil dan mutu benih beberapa varietas kedelai dengan variasi jumlah satuan panas panen. Pros Sem Nas Masy Biodiv Indon 2: 16-22. Penggunaan satuan panas panen untuk menguji mutu benih kedelai (Glycine max (L.) Merril)merupakan salah satu cara untuk mendapatkan hasil dan mutu kedelai yang baik. Penelitian ini dilaksanakan di lapangan di Kelurahan Pasar Ambacang, Kecamatan Kuranji, Kota Padang dan Laboratorium Teknologi Benih, Jurusan Budidaya Pertanian, Fakultas Pertanian, Universitas Andalas dari Oktober 2011 sampai Februari 2012. Penelitian ini bertujuan untuk mengetahui kombinasi yang tepat antara varietas kedelai dan waktu panen guna mendapatkan mutu benih yang terbaik, menentukan waktu panen yang tepat, serta mendapatkan varietas yang terbaik. Penelitian ini disusun secara faktorial dengan 3 kelompok dan 4 ulangan dalam Rancangan Acak Kelompok (RAK) yang terdiri dari 3 kelompok. Data hasil pengamatan dianalisis dengan uji F dan dilanjutkan dengan uji lanjut DNMRT pada taraf nyata 5\%. Hasil penelitian menunjukkan bahwa kombinasi antara varietas Bromo dan waktu panen dengan masukan energi satuan panas sebesar 1400-1450 SP memberikan hasil yang terbaik terhadap nilai indeks kecambah benih dibandingkan dengan perlakuan yang lain. Perbedaan waktu panen berpengaruh terhadap persentase uji muncul tanah, sedangkan perbedaan varietas kedelai berpengaruh terhadap bobot 100 biji pada kadar air 14\% dan bobot biji kering per plot.
\end{abstract}

Kata kunci: Glycine max, hasil, kedelai, mutu benih, satuan panas

\begin{abstract}
Dwipa I, Saswita W. 2016. Examination of yield and seed quality of several soybean varieties by variation of harvest thermal total unit. Pros Sem Nas Masy Biodiv Indon 2: 16-22. The using of thermal unit for examining the soybean (Glycine max (L.) Merril)is the best way for obtaining the best quality and result of soybean. The research was conducted in field of Pasar Ambacang, Kuranji Subdistrict, Padang City and Laboratory of Seed Technology, Department of Agronomy, Faculty of Agriculture, Andalas University, Padang from October 2011 to February 2012. This research aimed to determine the precise combination between soybean varieties and harvest time to obtain the best quality of seed, to determine the precise harvest time and to get the best variety. The research was arranged by factorial design of 3 x 4 in a Randomized Block Design (RBD) consisted of 3 groups. The data were analyzed by F test and continued by a further test of DNMRT at 5\% significance level. The result showed that a combination of Bromo variety and harvest time by energy input in the amount of 1400-1450 T was the best result for seed index value than the other treatments. The difference of harvest time influenced to the percentage of soil emerging test, while the difference of soybean variety influenced to the weight of 100 seeds on water content $14 \%$ and the weight of dry grain per plot.
\end{abstract}

Keywords: Glynie max, seed quality, soybean, thermal, yield

\section{PENDAHULUAN}

Kedelai merupakan salah satu komoditas utama kacangkacangan yang menjadi sumber protein nabati yang digemari masyarakat Indonesia (Sari 2014). Pemintaan kedelai di Indonesia terus menunjukkan peningkatan seiring dengan pertambahan jumlah penduduk dan pendapatan masyarakat (Marliah 2012). Besarnya permintaan kedelai belum diimbangi dengan produksi kedelai di dalam negeri. Hal ini menyebabkan sebagian besar kedelai di Indonesia harus diimpor dari luar negeri. Produksi rata-rata kedelai di Indonesia yang masih rendah disebabkan oleh beberapa faktor, diantaranya cara bercocok tanam yang kurang baik, proses fisiologis tanaman yang tidak sempurna, pemeliharaan yang tidak intensif, serta adanya serangan hama dan penyakit (Efendi 2010).

Untuk mengatasi hal tersebut perlu dicari varietas kedelai yang mempunyai sifat unggul, memperbaiki cara bercocok tanam, menyempurnakan proses fisiologis tanaman, serta pengendalian hama dan penyakit secara intensif yang semuanya mengarah pada usaha peningkatan hasil. Pematangan atau pemasakan kedelai merupakan faktor yang sangat penting dalam menciptakan mutu benih. 
Kesalahan waktu panen atau waktu panen yang tidak tepat dapat menurunkan mutu benih kedelai (Sarawa et al. 2012).

Waktu panen pada umumnya ditentukan dengan cara menghitung umur tanaman atau lebih dikenal dengan metode satuan hari. Pada metode ini, penentuan umur panen dengan menghitung hari sulit dijadikan patokan karena di lapangan umur suatu genotipe tanaman dapat berbeda sehubungan dengan tempat penanaman dan faktor lingkungan terutama suhu harian. Untuk menduga pematangan, pertumbuhan, hasil, dan mutu benih tanaman kedelai, lebih akurat digunakan metode satuan panas dibandingkan metode satuan hari. Metode tersebut tidak saja dapat menentukan saat matang, tetapi juga dapat menentukan umur dan saat panen yang dapat digunakan berdasarkan pendekatan secara klimatologi dan agronomi. Hingga saat ini, informasi mengenai penggunaan metode tersebut pada tanaman kedelai masih sedikit sekali, terutama berkaitan dengan varietas kedelai (Sulistyowati 2015).

Tujuan dari penelitian ini adalah untuk: (i) mengetahui kombinasi yang tepat antara varietas kedelai dan waktu panen guna mendapatkan mutu benih yang lebih baik, (ii) menentukan waktu panen yang tepat dengan metode satuan panas, sehingga memberikan hasil mutu benih yang terbaik, serta (iii) mengetahui varietas kedelai terbaik, baik mutu hasil maupun produksinya.

\section{BAHAN DAN METODE}

\section{Waktu dan tempat penelitian}

Penelitian ini dilaksanakan dari Oktober 2011 sampai Februari 2012 di lahan penduduk Kelurahan Pasar Ambacang, Kecamatan Kuranji, Kota Padang, Sumatera Barat dan Laboratorium Teknologi Benih, Jurusan Budidaya Pertanian, Fakultas Pertanian, Universitas Andalas, Padang, Sumatera Barat.

\section{Bahan dan alat}

Bahan yang digunakan meliputi benih kedelai varietas Wilis, Malabar, Argo Mulyo, dan Bromo, pupuk kandang, pupuk buatan (urea, SP-36, $\mathrm{KCl}$ ), pestisida, dan insektisida sintetik berbahan aktif karbofuran, sedangkan alat yang digunakan meliputi cangkul, sprayer, meteran, termometer maksimum-minimum, ember, timbangan, amplop kertas, kertas stensil, germinator datar, dan alat tulis.

\section{Metode penelitian}

Penelitian ini disusun secara faktorial dengan 3 kelompok dan 4 ulangan dalam Rancangan Acak Kelompok (RAK) dengan 3 kelompok, sehingga diperoleh 36 plot percobaan. Plot berukuran $175 \mathrm{~cm}$ x $175 \mathrm{~cm}$ dengan jarak tanam $25 \mathrm{~cm}$ x $25 \mathrm{~cm}$. Setiap plot terdiri dari 49 populasi, sehingga seluruhnya berjumlah 1.764 tanaman. Tiap-tiap plot terdiri dari 6 tanaman sampel.

Faktor pertama adalah waktu panen dengan 3 variasi jumlah masukan energi panas saat panen yaitu: 1340-1390 SP, 1400-1450 SP, dan 1460-1510 SP. Adapun faktor kedua adalah varietas kedelai yang terdiri dari varietas Wilis, Malabar, Argo Mulyo, dan Bromo. Pada penelitian ini terdapat 12 kombinasi perlakuan dan 3 kelompok perlakuan.

\section{Cara kerja}

Pengolahan tanah dilakukan sebanyak 2 kali dengan interval waktu satu minggu. Pada pengolahan lahan pertama, lahan dibersihkan dari sampah dan tumbuhan pengganggu lainnya. Plot dibuat dengan ukuran $175 \mathrm{~cm} \mathrm{x}$ $175 \mathrm{~cm}$ dengan jarak antarkelompok $50 \mathrm{~cm}$ dan jarak dalam kelompok $50 \mathrm{~cm}$. jarak tanam yang digunakan adalah $25 \mathrm{~cm}$ x $25 \mathrm{~cm}$. Pupuk kandang dicampur rata pada masing-masing plot sebanyak $3 \mathrm{~kg}$ per plot.

Pada tahap berikutnya, inokulasi tanah dilakukan dengan cara mencampurkan biji kedelai dengan tanah yang mengandung bakteri Rhizobium. Tanah yang digunakan berasal dari lahan bekas tanaman kedelai. Tanah yang mengandung bakteri Rhizobium dicampur dengan air agar tanah dapat melekat pada biji, kemudian biji dikeringanginkan terlebih dahulu sebelum ditanam. Pencampuran tersebut menggunakan perbandingan $9 \mathrm{~kg}$ biji : 9 kg tanah.

Penanaman dilakukan dengan cara menugalkan benih kedelai sebanyak 2 biji per lubang dengan kedalaman $3 \mathrm{~cm}$ dan jarak tanam $25 \mathrm{~cm}$ x $25 \mathrm{~cm}$. Jumlah plot yang dibuat sebanyak 36 plot dan jumlah tanaman sebanyak 49 tanaman tiap plot dengan 6 tanaman sampel tiap plotnya. Setelah semua benih ditanam, dilakukan pemupukan urea $50 \mathrm{~kg} / \mathrm{ha}$ atau setara dengan 15,3 g per plot, SP-36 100 $\mathrm{kg} / \mathrm{ha}$ atau setara dengan 30,6 g per plot, dan pupuk KCl 50 $\mathrm{kg} / \mathrm{ha}$ atau setara dengan 15,3 g per plot. Pupuk urea diberikan 2 kali. Pemupukan yang pertama diberikan pada waktu tanam sebanyak setengah dosis bersamaan dengan pupuk SP-36 dan $\mathrm{KCl}$, sedangkan pemupukan yang kedua diberikan pada waktu tanaman berumur 30 hari. Pupuk diberikan secara larikan. Dua minggu setelah penanaman, dilakukan pemeliharaan yang dimulai dari penjarangan dengan meninggalkan satu tanaman yang tumbuh seragam dari semua tanaman yang ada pada setiap plot. Penyiraman dilakukan setiap hari pada pagi hari kecuali turun hujan. Satu minggu sebelum panen, penyiraman dihentikan dengan tujuan untuk menurunkan kadar air pada biji kedelai. Selain penyiraman, penyiangan juga dilakukan untuk membersihkan gulma yang berada di sekitar tanaman. Penyiangan pertama dilakukan pada saat tanaman berumur 15 hari atau pada saat gulma mengganggu tanaman kedelai dan penyiangan selanjutnya dilakukan hampir setiap minggu. Untuk pengendalian hama kumbang daun (Phaedonia inclusa) yang menyerang tanaman kedelai selama percobaan berlangsung digunakan insektisida berbahan aktif deltamethrin dengan dosis 1 $\mathrm{ml} /$ liter air, sedangkan untuk tindakan pencegahan terhadap serangan hama dan penyakit diberikan insektisida berbahan aktif karbofuran sebanyak 4,25 kg/ha atau setara dengan 1,3 g per plot yang disebar secara merata di plot penanaman kemudian diaduk. Tahap terakhir yang dilakukan adalah pemanenan. Panen dilakukan apabila jumlah masukan panas telah mencapai jumlah yang diinginkan (sesuai masing-masing perlakuan). Panen dilakukan dengan cara memotong batang dekat permukaan tanah kemudian dikeringkan dengan cara dijemur di bawah sinar matahari sampai kering, kemudian biji dikeluarkan. 


\section{Parameter pengamatan}

Berat 100 biji pada kadar air 14\% (g)

Untuk menentukan berat 100 biji pada kadar air 14\% dapat dilakukan dengan menggunakan rumus:

Babat bift kering pada kadar alr $14 \%=\frac{20 w-A}{100-14} \times B$

A = kadar air biji saat penimbangan

$\mathrm{B}=$ berat biji pada kadar air A

Untuk menentukan kadar air biji dilakukan dengan cara menimbang biji terlebih dahulu (berat basah), setelah itu di-oven pada suhu $105^{\circ} \mathrm{C}$ selama 24 jam, kemudian ditimbang lagi (berat kering). Kadar air biji ditentukan dengan rumus:

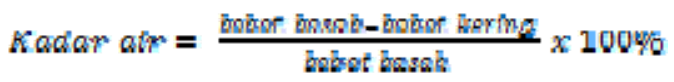

\section{Berat biji kering per plot}

Pengamatan terhadap berat biji kering per plot dilakukan dengan menimbang semua biji yang dihasilkan (tanaman sampel dan tanaman bukan sampel). Biji hasil panen dipisahkan menurut masing-masing perlakuan.

\section{Daya kecambah standar (\%)}

Pengamatan ini bertujuan untuk mengetahui daya kecambah benih. Lima puluh benih dikecambahkan dalam kertas stensil yang telah dibasahi air, sebanyak 3 lembar (2 lembar sebagai alas dan 1 lembar sebagai penutup). Pengamatan pertama dilakukan pada hari ke-5 sampai hari ke-13 atau hingga tidak ada lagi benih yang berkecambah. Daya kecambah ditentukan berdasarkan rumus berikut:

Daya kecambah standar $=\frac{z \text { henilh narwal }}{z \text { benth dikerawhahkan }} \times 100 \%$

\section{Perkecambahan hitung pertama/PHP (\%)}

Perkecambahan hitung pertama (first count test) bertujuan untuk menentukan kekuatan tumbuh dan daya kecambah benih. Caranya sama dengan pengujian daya kecambah standar. Pengamatan hanya dilakukan satu kali yaitu pada hari ke-5 setelah benih dikecambahkan. Perkecambahan hitung pertama dihitung menggunakan rumus:

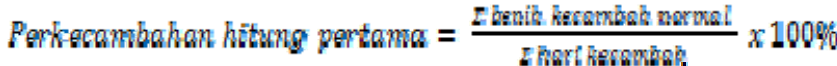

Pengujian nilai indeks kecambah (NIK)

Pengujian nilai indeks kecambah (index value test) bertujuan untuk menentukan kecepatan benih berkecambah dan kekuatan tumbuh benih. Caranya sama dengan pengujian daya standar kecambah, tetapi pengamatannya dilakukan setiap hari setelah benih dikecambahkan sampai hari ke-13 atau tidak ada lagi benih yang berkecambah. Nilai indeks dapat ditentukan menggunakan rumus:

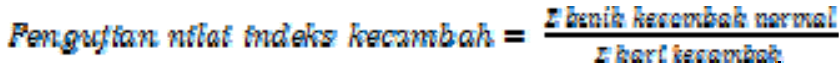

Uji muncul tanah/MT (\%)

Pengujian muncul tanah (soil emergence test) bertujuan untuk menentukan kekuatan tumbuh benih pada medium tanah. Benih ditanam pada media persemaian yang berisi tanah dan pasir dengan perbandingan 1:1 (v/v). Benih ditanam sebanyak 50 benih per media persemaian. Pengamatan dilakukan mulai pada hari ke-5 sampai ke-13 setelah benih ditanam dengan interval waktu 2 hari, dengan kriteria kotiledon telah terangkat $2 \mathrm{~cm}$ di atas permukaan media. Persentase muncul tanah dapat ditentukan dengan rumus berikut:

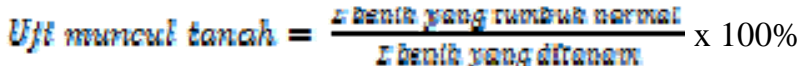

\section{Analisis data}

Data hasil pengamatan dianalisis secara statistik dengan sidik ragam. Jika $\mathrm{F}$ hitung $>\mathrm{F}$ tabel $5 \%$ maka dilanjutkan dengan Duncan's New Multiple Range Test (DNMRT) pada taraf nyata $5 \%$.

\section{HASIL DAN PEMBAHASAN}

\section{Berat 100 biji pada kadar air 14\%}

Hasil pengamatan berat 100 biji pada kadar air 14\% ditampilkan pada Tabel 1. Hasil pada Tabel 1 menunjukkan kombinasi antara jumlah masukan energi satuan panas dengan varietas kacang kedelai tidak memberikan pengaruh interaksi yang berbeda terhadap berat 100 biji pada kadar air 14\%. Perbedaan varietas kedelai memberikan pengaruh yang berbeda nyata terhadap 100 biji pada kadar air 14\%, sedangkan variasi jumlah masukan energi satuan panas memberikan pengaruh yang hampir sama terhadap berat 100 biji pada kadar air $14 \%$.

Hasil yang diperoleh menunjukkan bahwa varietas Argo Mulyo menghasilkan berat rata-rata 100 biji paling tinggi yaitu sekitar 13,15 g, kemudian diikuti oleh varietas Bromo dengan berat rata-rata 100 biji 11,76 g dan varietas Malabar dengan berat rata-rata 100 biji 10,77 g dan berat rata-rata 100 biji terendah diperoleh dari varietas Wilis yaitu sebesar 8,41 g. Sementara itu, berdasarkan variasi jumlah masukan energi satuan panas saat panen, berat biji tertinggi diperoleh pada saat panen dengan jumlah masukan energi satuan panas 1400-1450 SP (Gambar 2), kemudian diikuti oleh jumlah masukan energi satuan panas 1340-1390 SP (Gambar 1) dan berat biji terendah diperoleh dari pemanenan pada saat jumlah masukan energi satuan panas sebesar 1460-1510 SP (Gambar 3) .

Perbedaan tersebut diduga disebabkan oleh perbedaan genetik biji dan lingkungan. Faktor genetik yang mempengaruhi adalah kemampuan tanaman dalam menghasilkan jumlah dan besar biji, sedangkan faktor 
lingkungan diantaranya suhu, lama penyinaran, dan curah hujan selama pengisian biji yang akan mempengaruhi proses pengisian biji (Sinuraya et al. 2015). Marliah (2012) juga menyatakan bahwa perbedaan respons yang ditunjukkan oleh kedelai disebabkan oleh faktor genetik kedelai tersebut. Perbedaan sifat genetik mempengaruhi aktivitas pertumbuhan pada lingkungan yang berbeda, sehingga hasil yang diperoleh juga berbeda.

\section{Berat biji kering per plot}

Hasil pengamatan berat biji kering per plot yang dianalisis secara statistik dengan sidik ragam serta uji lanjutan pada taraf nyata 5\% ditampilkan pada Tabel 2. Hasil pada Tabel 2 menunjukkan bahwa kombinasi antara jumlah masukan energi satuan panas dan varietas kedelai tidak memberikan pengaruh interaksi yang berbeda terhadap berat biji kering per plot. Variasi jumlah masukan energi satuan panas tidak memberikan pengaruh yang berbeda terhadap berat biji kering per plot, sedangkan perbedaan varietas memberikan pengaruh yang berbeda nyata terhadap berat kering biji per plot.

Hasil penelitian menunjukkan bahwa varietas Bromo memberikan hasil tertinggi yaitu 129,22 g dan hasil terendah diperoleh dari varietas Wilis yaitu 324,44 g per plot (Tabel 2). Perbedaan varietas lebih mempengaruhi produksi dibandingkan dengan waktu panen yang didasarkan pada jumlah masukan energi satuan panas. Perbedaan masing-masing genotipe disebabkan oleh respons genetik masing-masing varietas terhadap lingkungan (Muis et al. 2013).

Pengaruh satuan panas yang diberikan terhadap waktu panen tidak menunjukkan pengaruh yang berarti (Tabel 2). Kualitas dan kuantitas hasil lebih dipengaruhi oleh potensi tiap-tiap genotipe yang memberikan hasil dan daya adaptasinya terhadap lingkungan (Dewi et al. 2013). Faktor genetik suatu varietas menyebabkan variasi spesies tanaman kedelai. Hal ini menyebabkan suatu varietas yang cocok pada kondisi lingkungan tertentu belum tentu cocok pada kondisi lingkungan lainnya dan setiap varietas juga mempunyai respons yang berbeda terhadap faktor-faktor eksternal seperti input yang diberikan pada tanaman (Efendi 2010).

\section{Daya kecambah standar (\%)}

Hasil pengamatan daya kecambah standar menunjukkan bahwa kombinasi antara jumlah masukan energi satuan panas dan varietas kedelai memberikan pengaruh interaksi yang berbeda tidak nyata terhadap daya kecambah standar (Tabel 3). Faktor perbedaan varietas kedelai juga menampilkan pengaruh yang berbeda tidak nyata terhadap daya kecambah standar benih. Faktor variasi jumlah masukan energi satuan panas juga memberikan pengaruh yang hampir sama terhadap daya kecambah standar benih (Situmeang et al. 2014).

Hasil tersebut disebabkan oleh saat matang fisiologis telah tercapai sebelum waktu panen dan penurunan mutu benih belum terjadi. Secara keseluruhan, keempat varietas kedelai yang digunakan mempunyai viabilitas yang tinggi karena rata-rata daya kecambah lebih dari 80\% meskipun kedelai dipanen dengan jumlah masukan energi panas yang berbeda. Marliah (2012) menyatakan bahwa tanaman akan menyesuaikan diri dan mengalami perubahan fisiologis dan morfologi sesuai dengan arah lingkungan barunya.

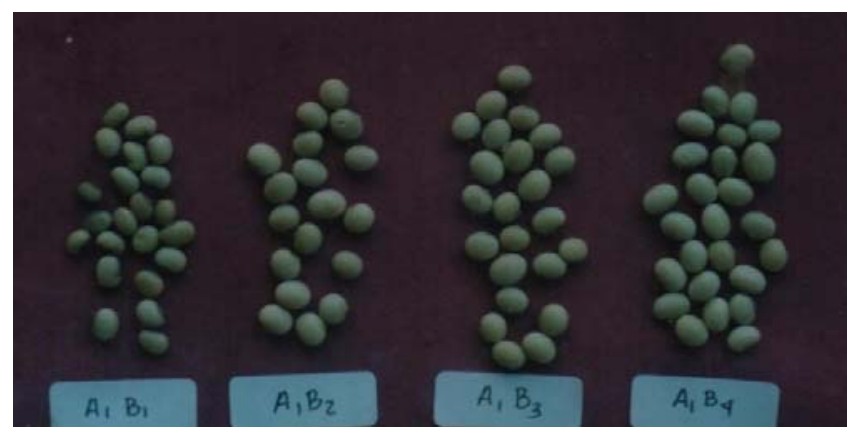

Gambar 1. Berat 100 biji pada kadar air 14\% (A1B1-A1B4) pada beberapa varietas kedelai yang dipanen pada jumlah masukan energi satuan panas sebesar 1340-1390 SP. $A_{1} B_{1}=$ Varietas Wilis dengan 1340-1390 SP, $\mathrm{A}_{1} \mathrm{~B}_{2}=$ varietas Malabar dengan 13401390 SP, $A_{1} B_{3}=$ varietas Argo Mulyo dengan 1340-1390 SP, dan varietas Bromo dengan 1340-1390 SP.

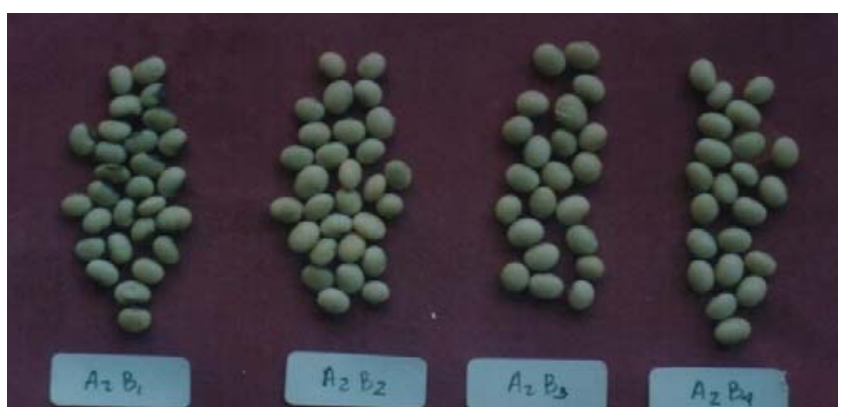

Gambar 2. Berat biji kering per plot (A2B1-A2B4) pada beberapa varietas kedelai yang dipanen pada jumlah masukan energi satuan panas sebesar 1400-1450 SP. $A_{2} B_{1}=$ Varietas Wilis dengan 1400-1450 SP, $\mathrm{A}_{2} \mathrm{~B}_{2}=$ varietas Malabar dengan 14001450 SP, $A_{2} B_{3}=$ varietas Argo Mulyo dengan 1400-1450 SP, dan $\mathrm{A}_{2} \mathrm{~B}_{4}=$ varietas Bromo dengan 1400-1450 SP.

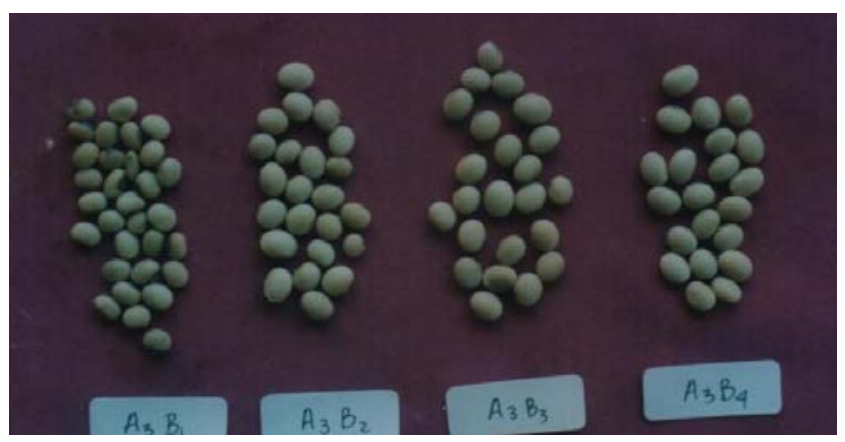

Gambar 3. Daya kecambah standar (A3B1-A3B4) pada beberapa varietas kedelai yang dipanen pada pada jumlah masukan energi satuan panas sebesar 1460-1510 SP. $\mathrm{A}_{3} \mathrm{~B}_{1}=$ Varietas Wilis dengan 1460-1510 SP, varietas Malabar dengan 1460-1510 SP, $\mathrm{A}_{3} \mathrm{~B}_{3}=$ varietas Argo Mulyo dengan 1460-1510 SP, dan $\mathrm{A}_{3} \mathrm{~B}_{4}=$ varietas Bromo dengan 1460-1510 SP. 


\section{Perkecambahan hitung pertama (\%)}

Hasil pengamatan menunjukkan bahwa kombinasi antara varietas kedelai dan jumlah masukan energi satuan panas memberikan pengaruh interaksi yang berbeda tidak nyata terhadap persentase perkecambahan hitung pertama (Tabel 4). Faktor varietas kedelai memberikan pengaruh yang hampir sama terhadap daya kecambah pada hitung pertama. Hasil yang serupa juga terlihat pada faktor variasi jumlah masukan energi satuan panas yang memberikan pengaruh hampir sama terhadap perkecambahan pada hitung pertama.

Perkecambahan awal dari benih lebih banyak dipengaruhi oleh kemampuan genetik benih itu sendiri serta kondisi lingkungan selama pertumbuhan. Antara viabilitas dan vigor mempunyai hubungan yang dapat dilihat pada daya kecambah dan perkecambahan hitung pertama. Benih yang mempunyai vigor yang tinggi akan memiliki viabilitas yang tinggi, sebaliknya benih yang mempunyai viabilitas tinggi belum tentu memiliki vigor yang tinggi (Permanasari 2014). Syamsudin et al. (2011) menyatakan bahwa varietas merupakan faktor yang berperan penting mempengaruhi pertumbuhan kedelai.

\section{Nilai indeks kecambah}

Hasil pengamatan nilai indeks kecambah (Tabel 5) menunjukkan bahwa kombinasi antara varietas kedelai dan jumlah masukan energi satuan panas saat panen memberikan pengaruh interaksi yang berbeda nyata terhadap nilai indeks kecambah. Faktor varietas kedelai menunjukkan pengaruh yang berbeda tidak nyata terhadap nilai indeks kecambah, sedangkan faktor variasi jumlah masukan energi satuan panas memberikan pengaruh yang berbeda nyata terhadap nilai indeks kecambah.

Kecepatan perkecambahan tertinggi terlihat pada kombinasi perlakuan varietas Bromo yang dipanen pada saat jumlah masukan energi satuan panas 1400-1450 SP yaitu sebesar 8,7\%, sedangkan kecepatan kecambah terendah diperoleh dari varietas Argo Mulyo yang dipanen pada saat jumlah masukan energi satuan panas 1460-1510 SP yaitu sebesar 6,3\%. Hasil ini menunjukkan bahwa waktu panen yang memberikan kecepatan perkecambahan paling tinggi adalah pada saat jumlah masukan energi satuan panas sebesar 1400-1450 SP.

Perbedaan munculnya radikula dan plumula pada kecambah erat kaitannya dengan kekuatan tumbuh benih. Benih yang memiliki kekuatan berkecambah dan kekuatan tumbuh tertinggi tergantung pada cadangan makanan yang terdapat dalam benih (Nusantara et al. 2010). Semakin tinggi vigor benih maka semakin cepat benih berkecambah. Pada saat masak fisiologis, benih memiliki berat kering maksimum, sehingga benih memiliki cadangan makanan yang cukup tersedia untuk tumbuh lebih cepat. Periode pramasak fisiologis yang memiliki kekuatan tumbuh benih masih rendah dan berangsur-angsur naik dan mencapai maksimum pada saat masak fisiologis. Benih yang vigornya paling rendah muncul paling lambat dalam fasefase awal pertumbuhan. Vigor dan viabilitas kedelai sangat dipengaruhi oleh faktor genetik suatu varietas (Indartono 2011).

\section{Uji muncul tanah (\%)}

Hasil pengamatan uji muncul tanah menunjukkan bahwa kombinasi antara jumlah masukan energi satuan panas dan varietas kedelai memberikan pengaruh interaksi yang berbeda tidak nyata terhadap kemampuan benih untuk muncul ke permukaan tanah (Tabel 6). Faktor variasi jumlah masukan energi satuan panas memberikan pengaruh yang berbeda nyata terhadap kemampuan benih untuk muncul ke permukaan tanah, sedangkan perbedaan varietas kedelai memberikan pengaruh yang hampir sama terhadap kemampuan benih untuk muncul ke permukaan tanah (Sihaloho et al. 2015) .

Panen dengan jumlah masukan energi satuan panas sebesar 1340-1390 SP memperlihatkan persentase daya kecambah tertinggi. Waktu panen pada jumlah satuan panas 1340-1390 SP dianggap lebih baik bagi benih untuk berkecambah dan tumbuh di lingkungannya (tanah) karena kondisinya yang optimal.

Perlakuan perbedaan varietas tidak memberikan pengaruh yang berarti karena semua varietas yang dipanen telah mencapai matang fisiologis dan mempunyai kemampuan untuk berkecambah secara optimal (Sulistyowati et al. 2015). Selain faktor internal benih, faktor eksternal juga mempengaruhi proses perkecambahan seperti air, gas, dan suhu (Syamsudin et al. 2011). Unsurunsur tersebut menjadi persyaratan utama dan harus selalu tersedia dan berada dalam kondisi optimal selama proses pengujian kekuatan kecambah, sehingga hasil yang diperoleh memiliki nilai tersendiri, sedangkan alat perkecambahan yang tersedia tidak memungkinkan mencapai kondisi tersebut (Tridiati et al. 2013).

Berdasarkan hasil penelitian dapat disimpulkan bahwa kombinasi antara varietas Bromo dengan waktu panen pada jumlah masukan energi satuan panas 1400-1450 SP memberikan hasil yang terbaik terhadap nilai indeks kecambah benih dibandingkan perlakuan lainnya. Perbedaan waktu panen berpengaruh terhadap uji muncul tanah, sedangkan perbedaan varietas berpengaruh terhadap bobot 100 biji pada kadar air 14\% dan bobot biji kering per plot.

Tabel 1. Berat 100 biji beberapa verietas kedelai pada kadar air $14 \%$ yang dipanen pada berbagai jumlah masukan energi satuan panas

\begin{tabular}{|c|c|c|c|c|c|}
\hline \multirow[b]{2}{*}{$\begin{array}{c}\text { Satuan panas } \\
\text { panen (SP) }\end{array}$} & \multicolumn{4}{|c|}{ Uji muncul tanah (\%) } & \multirow{2}{*}{$\begin{array}{c}\text { Pengaruh } \\
\text { utama } \\
\text { satuan panas } \\
\text { panen }\end{array}$} \\
\hline & Wilis & Malabar & $\begin{array}{c}\text { Argo } \\
\text { Mulyo }\end{array}$ & Bromo & \\
\hline $1340-$ & $8,40^{\mathrm{a}}$ & $10,73^{\mathrm{a}}$ & $12,37^{\mathrm{a}}$ & $11,86^{\mathrm{a}}$ & $10,84^{\mathrm{A}}$ \\
\hline $1400-1450$ & $8,29^{\mathrm{a}}$ & $11,38^{\mathrm{a}}$ & $14,17^{\mathrm{a}}$ & $12,32^{\mathrm{a}}$ & $11,54^{\mathrm{A}}$ \\
\hline $1460-1510$ & $8,55^{\mathrm{a}}$ & $10,21^{\mathrm{a}}$ & $12,91^{\mathrm{a}}$ & $12,91^{\mathrm{a}}$ & $11,12^{\mathrm{A}}$ \\
\hline $\begin{array}{l}\text { Pengaruh } \\
\text { utama varietas }\end{array}$ & $8,41^{\mathrm{D}}$ & $10,77^{\mathrm{C}}$ & $13,15^{\mathrm{A}}$ & $11,76^{\mathrm{B}}$ & \\
\hline
\end{tabular}

Keterangan: Angka-angka pada kolom yang sama yang diikuti dengan huruf yang sama memberikan pengaruh berbeda tidak nyata menurut DNMRT pada taraf nyata 5\%. 
Tabel 2. Berat biji kering per plot beberapa varietas kedelai yang dipanen pada berbagai jumlah masukan energi satuan panas

\begin{tabular}{|c|c|c|c|c|c|}
\hline \multirow[b]{2}{*}{$\begin{array}{c}\text { Satuan panas } \\
\text { panen (SP) }\end{array}$} & \multicolumn{4}{|c|}{ Uji muncul tanah (\%) } & \multirow{2}{*}{$\begin{array}{c}\text { Pengaruh } \\
\text { utama } \\
\text { satuan panas } \\
\text { panen }\end{array}$} \\
\hline & Wilis & Malabar & $\begin{array}{c}\text { Argo } \\
\text { Mulyo }\end{array}$ & Bromo & \\
\hline $1340-1390$ & $385,00^{\mathrm{a}}$ & $335,00^{\mathrm{a}}$ & $470,00^{\mathrm{a}}$ & $618,33^{\mathrm{a}}$ & $452,08^{\mathrm{A}}$ \\
\hline $1400-1450$ & $263,33^{\mathrm{a}}$ & $373,33^{\mathrm{a}}$ & $535,00^{\mathrm{a}}$ & $726,67^{\mathrm{a}}$ & $474,58^{\mathrm{A}}$ \\
\hline $1460-1510$ & $325,00^{a}$ & $279,33^{\mathrm{a}}$ & $502,00^{\mathrm{a}}$ & $842,67^{\mathrm{a}}$ & $487,25^{\mathrm{A}}$ \\
\hline $\begin{array}{l}\text { Pengaruh } \\
\text { utama varietas } \\
\text { kedelai }\end{array}$ & $324,44^{\mathrm{C}}$ & $329,22^{\mathrm{C}}$ & $502,33^{\mathrm{B}}$ & $729,22^{\mathrm{A}}$ & \\
\hline
\end{tabular}

Keterangan: Angka-angka pada kolom yang sama yang diikuti dengan huruf yang sama memberikan pengaruh berbeda tidak nyata menurut DNMRT pada taraf nyata 5\%

Tabel 3. Daya kecambah standar benih beberapa varietas kedelai yang dipanen pada berbagai jumlah energi satuan panas

\begin{tabular}{lccccc}
\hline \multirow{2}{*}{$\begin{array}{c}\text { Satuan panas } \\
\text { panen (SP) }\end{array}$} & Wilis & Malabar & $\begin{array}{c}\text { Argo } \\
\text { Mulyo }\end{array}$ & Bromo & $\begin{array}{c}\text { Pengaruh } \\
\text { utama } \\
\text { satuan panas } \\
\text { panen }\end{array}$ \\
\hline $1340-1390$ & $88,00^{\mathrm{a}}$ & $92,00^{\mathrm{a}}$ & $90,00^{\mathrm{a}}$ & $84,00^{\mathrm{a}}$ & 88,50 \\
$1400-1450$ & $91,33^{\mathrm{a}}$ & $90,67^{\mathrm{a}}$ & $90,67^{\mathrm{a}}$ & $95,33^{\mathrm{a}}$ & 92,00 \\
$1460-1510$ & $88,00^{\mathrm{a}}$ & $84,00^{\mathrm{a}}$ & $80,00^{\mathrm{a}}$ & $94,00^{\mathrm{a}}$ & 86,50 \\
$\begin{array}{l}\text { Pengaruh } \\
\text { utama varietas }\end{array}$ & 89,11 & 88,89 & 86,89 & 91,11 & 89,00 \\
\hline
\end{tabular}

kedelai

Keterangan: Angka-angka pada kolom yang sama yang diikuti dengan huruf yang sama memberikan pengaruh berbeda tidak nyata menurut uji DNMRT pada taraf nyata 5\%.

Tabel 4. Perkecambahan hitung pertama beberapa varietas kedelai yang dipanen pada berbagai jumlah masukan energi satuan panas

\begin{tabular}{lccccc}
\hline \multirow{4}{*}{$\begin{array}{c}\text { Satuan panas } \\
\text { panen (SP) }\end{array}$} & Wilis & Malabar & $\begin{array}{c}\text { Argo } \\
\text { Mulyo }\end{array}$ & Bromo & $\begin{array}{c}\text { Pengaruh } \\
\text { utama } \\
\text { satuan panas } \\
\text { panen }\end{array}$ \\
\hline $1340-1390$ & 86,67 & 87,33 & 89,33 & 72,00 & 83,83 \\
$1400-1450$ & 91,33 & 78,67 & 86,00 & 87,33 & 85,83 \\
$1460-1510$ & 87,33 & 83,73 & 74,67 & 85,33 & 82,66 \\
$\begin{array}{l}\text { Pengaruh } \\
\text { utama varietas }\end{array}$ & 88,44 & 83,11 & 83,33 & 81,55 & \\
kedelai & & & & & \\
\hline Kelannn
\end{tabular}

Keterangan: Angka-angka pada kolom yang sama yang diikuti dengan huruf yang sama memberikan pengaruh berbeda tidak nyata menurut uji DNMRT pada taraf nyata 5\%

Tabel 5. Nilai indeks kecambah beberapa varietas kedelai yang dipanen pada berbagai jumlah masukan energi satuan panas

\begin{tabular}{ccccc}
\hline Satuan & \multicolumn{4}{c}{ Nilai indeks kecambah } \\
\cline { 2 - 5 } $\begin{array}{c}\text { panas } \\
\text { panen (SP) }\end{array}$ & Wilis & Malabar & $\begin{array}{c}\text { Argo } \\
\text { Mulyo }\end{array}$ & Bromo \\
\hline $1340-1390$ & $7,7^{\mathrm{A} \mathrm{a}}$ & $7,9^{\mathrm{Ba}}$ & $7,8^{\mathrm{B} \mathrm{a}}$ & $7,4^{\mathrm{Bb}}$ \\
$1400-1450$ & $7,5^{\mathrm{A} \mathrm{c}}$ & $8,2^{\mathrm{A}}$ & $8,5^{\text {A }}$ & $8,7^{\mathrm{A}}$ \\
$1460-1510$ & $7,1^{\mathrm{B}}$ & $6,6^{\mathrm{C}}$ & $6,3^{\text {C }}$ & $7,7^{\text { a }}$ \\
\hline
\end{tabular}

Keterangan: Angka-angka pada kolom yang sama yang diikuti dengan huruf yang sama memberikan pengaruh yang tidak berbeda nyata menurut uji DNMRT pada taraf uji 5\%.
Tabel 6. Uji muncul tanah beberapa varietas kedelai yang dipanen pada berbagai jumlah masukan energi satuan panas

\begin{tabular}{lccccc}
\hline \multirow{4}{*}{$\begin{array}{c}\text { Satuan panas } \\
\text { panen (SP) }\end{array}$} & Wilis & Malabar & $\begin{array}{c}\text { Argo } \\
\text { Mulyo }\end{array}$ & Bromo & $\begin{array}{c}\text { Pengaruh } \\
\text { utama } \\
\text { satuan panas } \\
\text { panen }\end{array}$ \\
\hline $1340-1390$ & 93,33 & 98,00 & 99,33 & 100,00 & $97,66^{\mathrm{A}}$ \\
$1400-1450$ & 96,00 & 94,67 & 94,00 & 98,00 & $95,67^{\mathrm{B}}$ \\
$\begin{array}{l}1460-1510 \\
\begin{array}{l}\text { Pengaruh } \\
\text { utama varietas }\end{array}\end{array}$ & 94,00 & 82,67 & 93,33 & 86,00 & $89,00^{\mathrm{C}}$ \\
kedelai & 94,44 & 91,78 & 95,55 & 94,67 & \\
\hline
\end{tabular}

Keterangan: Angka-angka pada kolom yang sama yang diikuti dengan huruf yang sama memberikan pengaruh berbeda tidak nyata menurut uji DNMRT pada taraf uji 5\%.

\section{UCAPAN TERIMA KASIH}

Dana penelitian ini merupakan dana pribadi dan terima kasih diucapkan kepada Dekan Fakultas Pertanian, Universitas Andalas Padang yang telah memberikan fasilitas untuk penelitian ini dan terima kasih juga disampaikan kepada semua pihak yang telah membantu penelitian ini.

\section{DAFTAR PUSTAKA}

Alia Y, Wilia W. 2010. Persilangan empat varietas kedelai dalam rangka penyediaan populasi awal untuk seleksi. Jurnal Penelitian Universitas Jambi: Seri Sains 13 (1): 39-42.

Dewi R, Sutrisno H, Nazirwan. 2013. Pemulihan deteriorasi benih kedelai (Glycine max L.) dengan aplikasi giberalin. Jurnal Penelitian Pertanian Terapan 13 (2): 116-122.

Efendi. 2010. Peningkatan pertumbuhan dan produksi kedelai melalui kombinasi pupuk organik lamtorogung dengan pupuk kandang. J Floratek 5: 65-73.

Indartono. 2011. Pengkajian suhu ruang penyimpanan dan teknik pengemasan terhadap kualitas benih kedelai. Gema Teknologi 16 (3): 158-163.

Lubis NA, Rosmayati, Hanafiah DS. 2015. Persilangan genotipe-genotipe kedelai (Glycine max (L.) Merrill.) hasil seleksi pada tanah salin dengan tetua betina varietas Grobogan. Jurnal Online Teknologi 3 (1): 291-298.

Marliah A, Hidayat T, Husna N. Pengaruh varietas dan jarak tanam terhadap pertumbuhan kedelai (Glycine max (L.) Merril). J Agrista 16 (1): 22-28.

Muis A, Indradewa D, Widada J. 2013. Pengaruh inokulasi mikoriza arbuskula terhadap pertumbuhan dan hasil kedelai (Glycine max (L.) Merril) pada berbagai interval penyiraman. Jurnal Vegetalika 2 (2): 720.

Nusantara AD, Kusuma C, Mansur I. 2010. Pemanfaatan vermikompos untuk produksi biomassa legum penutup tanah dan inokulum fungi mikoriza. Jurnal Ilmu-Ilmu Pertanian Indonesia 12 (1): 26-33.

Permanasari I, Irfan M, Abizar. 2014. Pertumbuhan dan hasil kedelai (Glycine max (L.) Merill) dengan pemberian Rhizobium dan pupuk urea pada media gambut. Jurnal Agroteknologi 5 (1): 29-34.

Sarawa, Nurmas A, Aj MD. 2012. Pertumbuhan dan produksi tanaman kedelai (Glycine max L.) yang diberi pupuk guano dan mulsa alangalang. J Agroteknos 2 (2): 97-105.

Sari DA, Hasanah Y, Siamnungkalit T. 2014. Respons pertumbuhan dan produksi beberapa varietas kedelai Glycine max L. (Merril) dengan pemberian pupuk organik cair. Agroekoteknologi 2 (2): 653-661.

Sihaloho NS, Rahmawati N, Putri LAP. 2015. Respons pertumbuhan dan produksi tanaman kedelai varietas Detam 1 terhadap pemberian vermikompos dan pupuk P. Agroekoteknologi 3 (4): 1591-1600. 
Sinuraya MA, Barus A, Hasanah Y. 2015. Respons pertumbuhan dan produksi kedelai (Glycine max (L.) Meriil) terhadap konsentrasi dan pemberian pupuk cair. Jurnal Agroekoteknologi 4 (1): 1721-1725.

Situmeang M, Purwantoro A, Sulandari S. 2014. Pengaruh pemanasan terhadap perkecambahan dan kesehatan benih kedelai (Glycine max (L.) Merrill). J Vegetalika 3 (3): 27-37.

Sulistyowati TE, Purnomo D, Pujiasmanto B. 2015. Pengaruh umur panen terhadap hasil dan kualitas benih tiga varietas kedelai (Glycine max (L.) Merril). Jurnal El-Vivo 3 (2): 22-33.
Syamsudin, Syafruddin, Hasanuddin. 2011. Pengujian model simulasi vigor kekuatan tumbuh benih kedelai Glycine max L. (Merril) pada kondisi lahan stres oksigen. J Floratek 6: 37-47.

Tridiati, Mubarik NRM, Ramasita Y. 2013. Respons pertumbuhan tanaman kedelai terhadap Bradyrhizobium japonicum toleran masam dan pemberian pupuk di tanah masam. Jurnal Agronomi Indonesia 41 (1): 24-31. 